\title{
Application Of Resilient Long-Short Strategies For Taiwanese Hedge Funds
}

Heng-Hsing Hsieh, PhD, CFA, University of the Western Cape, South Africa

Kathleen Hodnett, PhD, University of the Western Cape, South Africa

\begin{abstract}
This paper proposes a 4-step approach in developing resilient long-short hedge fund strategies for stocks traded on the Taiwan Stock Exchange. The two hedge fund strategies developed in this research, namely the Hybrid Neutral Fund and the Defense Fund, outperform their respective benchmarks on a risk-adjusted basis over the examination period from 01 January 2000 to 31 December 2011. In addition, both hedge fund strategies efficiently mitigate the drawdowns during turbulent times. The total returns on the TAIEX Index (the market proxy) is found to be a meanvariance inefficient portfolio over the examination period. The Hybrid Neutral Fund that takes the advantage from both the traditional market neutral fund and the Defense Fund is found to achieve the highest risk-adjusted performance over the examination period.
\end{abstract}

Keywords: Tactical Style Allocation; Style Timing; Style Rotation; Value Stocks; Momentum Stocks; Active and Passive Portfolio Management; Value Investing; Momentum Investing; Taiwan Stock Exchange; TAIEX; Hedge Fund Strategies

\section{INTRODUCTION}

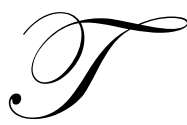

he relative performance of investment styles is correlated with the states of the economic cycle. Style rotation strategies that aim at exploring the optimal allocations in a style-based portfolio could provide ample economic benefits compared to a static portfolio. In the presence of substantial systemic risk during global financial crises, market timing strategies could be developed to provide protection during turbulent times. Thus, resilient hedge fund strategies that aim at both market timing and style timing throughout different states of the economic cycle could be developed to provide equity-like return with bond-like risk. This paper proposes a 4-step procedure to developing hedge fund strategies on the Taiwan Stock Exchange that are resilient during turbulent times, with its underlying returns driven by rotated investment styles over the period from 01 January 2000 to 31 December 2009. The two major market crises during this period include the burst of the dot-com bubble in the early 2000s and the global financial market crash in 2008.

Under the 4-step procedure, we design a model based on a genetic algorithm where the style attributes of a stock are regarded as the genes of that stock and the stock composition of a fund is regarded as the fund's "genetic makeup". Tactical style allocation (TSA) of a fund determines the "attitude" of the fund. Protection mechanisms regarding the cash reservation rate of the fund, the proportion of the fund that is hedged, as well as the timing of the hedge, represents the unique risk-return characteristics of the hedging strategy. Two hedge fund strategies are developed under the 4-step procedure, namely the Hybrid Neutral Fund and the Defense Fund. The risk-adjusted performance of the TAIEX Index and the unprotected (long-only) style-based portfolio will be compared to the hedge fund strategies developed under the 4-step procedure.

\section{KEY CONSIDERATIONS}

As one of the fastest growing emerging economies in South East Asia, Taiwan is periodically flooded with 'hot money', which has the potential of causing asset bubbles, and a stronger Taiwanese currency that hampers the country's competitiveness. The local market proxy is the cap-weighted TAIEX Index with approximately 1,700 stocks as its constituents. Trading activities on the Taiwan Stock Exchange are highly volatile with an annualized 
standard deviation of over $25 \%$ per annum. Frequent monetary interventions during turbulent times and elections at key support levels are expected. Dividend declarations are generally concentrated in July and August, which results in significant backwardation in TAIEX futures (a situation when the futures price is lower than the underlying index spot price). It is also important to note that Taiwanese stocks are first issued at a denomination of 10 Taiwanese dollars per share. This means that stocks that trade for higher than 10 Taiwanese dollars per share creates shareholder value since inception, while shares trading at less than 10 Taiwanese dollars per share fail to create shareholder value since inception.

With regard to the explanatory power of the style attributes on the Taiwan Stock Exchange, Sheu, Wu and $\mathrm{Ku}$ (1998) examine the determinants of the cross-sectional returns on the Taiwan Stock Exchange over the period from July 1976 to June 1996. The authors focus their research on the influences of market beta, trading volume and the sales-to-price ratio. All three attributes are found to significantly explain the cross-section of Taiwanese stock returns. The research results reveal that the sales-to-price ratio is the most significant attribute among the three variables under investigation in both up and down markets. The authors also find a reversal in long-term returns. In summary, stocks with relatively high sales-to-price, low trading volumes and low long-term returns are likely to outperform the market. Sheu et al (1998) attribute their study results to investor overreaction. Chen and Tu (2000) investigate the relative power of risk proxies and firm characteristics in explaining the returns of stocks traded on the Taiwan Stock Exchange over the period from 1995 to 1998. The authors conclude that either model alone cannot fully explain Taiwanese stock returns and argue that using either approach in isolation would lose important information in the pricing of the Taiwanese stocks. Cheng, Lai and Tsai (2005) conduct a two-stage test of the Fama-French 3-factor model on the Taiwan Stock Exchange over the period from December 1981 through June 2002. Their results show that while the influences of the market proxy remains significant, the value effect appears to be weak on the Taiwan Stock Exchange over the examination period.

Shyu, Jeng, Ton, Lee and Chuang (2006) propose the use of multifactor models to develop market neutral strategies for Taiwanese stocks. The main objectives of the market neutral strategies identified by Shyu et al (2006) include providing absolute returns, having low correlation with the equity benchmark and mitigating volatility due to hedged portfolio structures. The blended fundamental-technical model employs 28 macroeconomic and firmspecific variables to measure asset risks and returns for dynamic market neutral portfolios. The design involves 6 main steps in developing market neutral funds, namely (1) finding information and determining the target factor, (2) sorting and ranking using a non-parametric approach, (3) calculating and ranking realized sample returns and comparing it to the benchmark, (4) testing sample performance and determining the long-short market neutral strategy, (5) predicting the return and risk covariance matrix, and (6) optimizing and constructing the market neutral portfolio. Based on this procedure, the market neutral fund is constructed with its performance evaluated over the period from January 1999 to December 2003. Their results indicate that the market neutral fund developed based on the 6-step procedure outperforms the total returns on the TAIEX Index on a risk-adjusted basis in terms of the Sharpe ratio over the examination period.

\section{FUND DEVELOPMENT PROCEDURE}

Style attributes of the stocks comprising the TAIEX Index as of 1 January 2011 are obtained from the Taiwanese Economic Journal (TEJ) Database. The back-testing period spans from 01 January 2000 to 31 December 2009 (a total of 120 months). A monthly-rebalanced equity portfolio is first constructed as the long-only portfolio using the largest 50 stocks based on the market capitalization at the beginning of each month. The four major steps in developing a resilient investment strategy proposed by this research are as follows:

Step 1 Determining the Optimal "Genetic Makeup (DNA)" of the fund;

Step 2 Determining the "Attitude" of the fund;

Step 3 Determining the "Protection Mechanism" of the fund; and

Step 4 Additional "Mandatory Requirements" of the fund. 


\section{Step 1 Determining the Optimal "Genetic Makeup (DNA)" of the Fund}

The attitude of a fund is decomposed into four investment styles, namely (1) Fundamental Values, (2) Technical Trends, (3) Momentum and (4) Financial Ratios. Using the analogy of a genetic algorithm, investment styles can be regarded as "chromosomes", which are comprised of a set of "genes" or the stock's style attributes (see Table 1):

Table 1: Genetic Makeup of a Fund

\begin{tabular}{|c|c|c|c|c|}
\hline $\begin{array}{l}\text { Investment Styles } \\
\text { (Chromosomes): }\end{array}$ & Fundamental Values & Technical Trends & Momentum & Financial Ratios \\
\hline $\begin{array}{l}\text { Style Attributes } \\
\text { (Genes) Under } \\
\text { Each Style Category: }\end{array}$ & $\begin{array}{l}\text { (1) Book Value } \\
\text { (2) Earnings } \\
\text { (3) Dividends } \\
\text { (4) Net Cash Flow } \\
\text { (5) Sales }\end{array}$ & $\begin{array}{l}\text { (1) 3-month moving } \\
\text { average crossover } \\
\text { (2) 6-month moving } \\
\text { average crossover } \\
\text { (3) Relative Strength } \\
\text { Indicator }\end{array}$ & $\begin{array}{l}\text { (1) Past 12-month } \\
\text { Returns } \\
\text { (2) Past 6-month } \\
\text { Returns } \\
\text { (3) Past 1-month } \\
\text { returns }\end{array}$ & $\begin{array}{l}\text { (1) Earnings Yield } \\
\text { (2) Dividend Yield } \\
\text { (3) Debt-to-Equity } \\
\text { (4) Interest Coverage } \\
\text { (5) Return-on-Equity }\end{array}$ \\
\hline
\end{tabular}

The optimal makeup of the genes (style attributes) for each chromosome (investment style) is estimated using a genetic algorithm (GA) proposed in Hodnett and Hsieh (2012). Thus, the final candidates (of stocks) representing the "survival of the fittest" (based on evolutionary theory and natural selection) are retained in the fund.

\section{Step 2 Determining the "Attitude" of the Fund}

While the genetic makeup (DNA) of a fund determines the natural ability of the fund in terms of performance, the attitude of the fund is determined by its style composition. For example, a fund that allocates $80 \%$ of its capital to momentum stocks and the rest to value stocks is considered more aggressive than a fund that splits its investment equally between the momentum and value investment styles. The optimal style composition/style mix is determined by the tactical style allocation (TSA) method proposed by Hsieh, Hodnett and van Rensburg (2012a) using weighted least squares (WLS) regressions.

\section{Step 3 Determining the "Protection Mechanism" of the Fund}

Factors to be considered include cash reservation (percentage of the fund value that is not to be invested), percentage of the invested value to be hedged, and the timing of the hedge being triggered and subsequently lifted. For example, a fund with a market value of $\$ 1,000,000$ and a cash reservation rate of $20 \%$ means that only $\$ 800,000$ is invested. If the hedged portion is equal to $50 \%$ of the invested value, the fund manager would have to hold a short futures position (or long put position) equivalent to $\$ 400,000$ during the hedged period.

On the other hand, the timing of the hedge is specified using a filter that is triggered when the invested assets drop $10 \%$ (the maximum tolerable drawdown filter) in value, and lifts the hedge when the invested value rebounds by at least 5\% (the minimum required drawup filter) based on the filter rule protection strategy proposed by Hsieh, Hodnett and van Rensburg (2012b). This means that the hedge is triggered when the invested value drops to $\$ 720,000$ (from $\$ 800,000$ ). If the invested value drops to $\$ 600,000$ since the hedge is triggered, and subsequently rebounds by $5 \%$ to $\$ 630,000$, the hedge will be lifted. However, if the invested value drops back to $\$ 600,000$, the hedge will be triggered again. A market neutral strategy would mean that $100 \%$ of the invested value is protected at all times. 


\section{Step 4 Additional "Mandatory Requirements" of the Fund}

Rebalancing frequency (for example, weekly, monthly or quarterly) of the fund has to be determined. Frequent rebalancing entails higher transaction costs. A maximum constituent weight is specified. A maximum weight of $10 \%$ on any single investment is recommended to achieve sufficient diversification benefits. Investment restrictions on sin-stocks (for example, tobacco manufacturers) may be placed by the clients.

\section{RESULTS}

Funds being developed include ${ }^{1}$ Market Benchmark, ${ }^{2}$ Unprotected Fund (long-only), ${ }^{3}$ Hybrid Neutral Fund and ${ }^{4}$ Defense Fund. Short futures contracts on the ${ }^{1}$ Market Benchmark are used to manage the risk in the ${ }^{2}$ Unprotected Fund to form the ${ }^{3}$ Hybrid Neutral Fund and the ${ }^{4}$ Defense Fund. The ${ }^{3}$ Hybrid Neutral Fund is constantly protected by short futures positions, which depends on the specified protection level (for example, 50\%) until the long position of the fund falls below the maximum tolerable drawdown filter. When this happens, additional short futures are used to raise the protection level to $100 \%$ (neutral position). When the unprotected fund bounces above the minimum acceptable drawup filter, the additional protection is removed and the specified protection level applies.

The ${ }^{3}$ Hybrid Neutral Fund is an improved version of a typical market neutral fund. The ${ }^{3}$ Hybrid Neutral Fund is only partially covered during non-turbulent times. During turbulent times, the ${ }^{3}$ Hybrid Neutral Fund takes on additional protection and becomes a typical market neutral fund with $100 \%$ of the invested amount being hedged. The advantage of being partially covered prevents the fund from underperforming at the peak of the stock market bubble, yet ready to go neutral when the bubble bursts.

The ${ }^{4}$ Defense Fund remains unprotected until the maximum tolerable filter is exceeded. When this happens, the fund is entirely $(100 \%)$ protected by short futures. Short futures contracts are subsequently removed when the long position of the fund bounces up above the minimum acceptable drawup filter.

Depending on the industry structure and investor behavior in the market, strategies applying to different markets are adjusted to tackle the weaknesses of the local market. Exhibit 1 demonstrates outstanding performance of the ${ }^{2}$ Unprotected Fund of 50 Taiwanese stocks, the ${ }^{3}$ Hybrid Neutral Fund and the ${ }^{4}$ Defense Fund over the examination period. These 3 funds achieved annualized returns that are substantially higher than the annualized return of the TAIEX total return index over the 10-year examination period. The highly volatile Taiwanese stock market, accompanied by the influences of 'hot money', an unstable political environment and government intervention contribute to the limited performance of the TAIEX total return index over time.

Both the ${ }^{3}$ Hybrid Neutral Fund and the ${ }^{4}$ Defense Fund consistently earn positive returns in almost all years of the examination period. Protection mechanisms are necessary to mitigate the highly-risky ${ }^{2}$ Unprotected Fund (Beta of 1.23, annualized standard deviation of $38.82 \%$ and maximum drawdown of $-42.80 \%$ ). Small drawdown and drawup filters (-5\% and 5\%) are necessary to handle substantial temporary shocks in the volatile market (see Exhibit 2). The flexible, yet cautious ${ }^{3}$ Hybrid Neutral Fund is most suitable to investing on the Taiwan Stock Exchange. TAIEX futures is a good hedging instrument for the ${ }^{2}$ Unprotected Fund as the maximum drawdowns of the ${ }^{3}$ Hybrid Neutral Fund and the ${ }^{4}$ Defense Fund are substantially lower than that of the ${ }^{2}$ Unprotected Fund.

The cumulative returns of the funds are shown in Exhibit 3. The periodic drawdowns are observed from Exhibit 4. During the 10-year evaluation period, the maximum tolerable drawdown filter of $-10 \%$ has been triggered 12 times. The adequate lifts of the hedge triggered by the 5\% minimum required drawup filter have resulted in both the ${ }^{3}$ Hybrid Neutral Fund and the ${ }^{4}$ Defense Fund accumulating values much faster than the ${ }^{2}$ Unprotected Fund. 


\begin{tabular}{ll}
\hline Cash Reservation Rate: & $20 \%$ \\
Drawdown Filter: & $-10 \%$ \\
Drawup Filter: & $+5 \%$
\end{tabular}

\begin{tabular}{llccc}
\hline & ${ }^{1}$ TAIEX & ${ }^{\mathbf{2} U n p r o t e c t e d ~ F u n d ~}$ & ${ }^{\mathbf{3}}$ Hybrid Neutral Fund & ${ }^{\mathbf{4} D e f e n s e ~ F u n d ~}$ \\
\hline & & & Level of Protection: & Level of Protection: \\
& & & $80 \%$ & $100 \%$ \\
2000 & $-36.41 \%$ & $-20.48 \%$ & $25.63 \%$ & $28.51 \%$ \\
2001 & $15.18 \%$ & $60.64 \%$ & $48.35 \%$ & $61.05 \%$ \\
2002 & $-15.76 \%$ & $16.61 \%$ & $35.84 \%$ & $26.57 \%$ \\
2003 & $25.75 \%$ & $62.86 \%$ & $38.98 \%$ & $59.62 \%$ \\
2004 & $3.69 \%$ & $27.88 \%$ & $24.80 \%$ & $24.30 \%$ \\
2005 & $5.47 \%$ & $13.14 \%$ & $5.47 \%$ & $-1.23 \%$ \\
2006 & $15.49 \%$ & $24.08 \%$ & $9.68 \%$ & $17.67 \%$ \\
2007 & $7.13 \%$ & $11.93 \%$ & $6.41 \%$ & $12.79 \%$ \\
2008 & $-38.37 \%$ & $-30.04 \%$ & $11.45 \%$ & $2.67 \%$ \\
2009 & $60.01 \%$ & $72.17 \%$ & $16.95 \%$ & $52.01 \%$ \\
\hline
\end{tabular}

Exhibit 2: Performance Statistics

\begin{tabular}{|c|c|c|c|}
\hline${ }^{1}$ TAIEX & ${ }^{2}$ Unprotected Fund & ${ }^{3}$ Hybrid Neutral Fund & ${ }^{4}$ Defense Fund \\
\hline & & $\frac{\text { Level of Protection: }}{80 \%}$ & $\frac{\text { Level of Protection: }}{100 \%}$ \\
\hline \multicolumn{4}{|c|}{ Annualized Geometric Return: } \\
\hline $0.35 \%$ & $19.36 \%$ & $21.56 \%$ & $26.67 \%$ \\
\hline \multicolumn{4}{|c|}{ Cumulative Return from NT\$1 (2000 to 2009): } \\
\hline NT\$ 1.04 & NT\$ 5.87 & NT\$ 7.04 & NT\$ 10.63 \\
\hline \multicolumn{4}{|c|}{ Annualized Standard Deviation: } \\
\hline $27.55 \%$ & $38.82 \%$ & $21.13 \%$ & $31.72 \%$ \\
\hline \multicolumn{4}{|c|}{ Beta Coefficient: } \\
\hline 1.00 & 1.23 & 0.35 & 0.83 \\
\hline \multicolumn{4}{|c|}{ Max. Drawdown: } \\
\hline$-54.17 \%$ & $-42.80 \%$ & $-11.38 \%$ & $-18.24 \%$ \\
\hline \multicolumn{4}{|c|}{ Consecutive Positive-to-Negative Monthly Returns: } \\
\hline $6 / 7$ & $8 / 5$ & $6 / 4$ & $8 / 4$ \\
\hline
\end{tabular}


Exhibit 3: Cumulative Returns and Exposure Periods

Protection Periods $\longrightarrow$ TAIEX $\longrightarrow$ Unprotected Fund $\longrightarrow$ Hybrid Neutral Fund $\longrightarrow \rightarrow$ Defense Fund

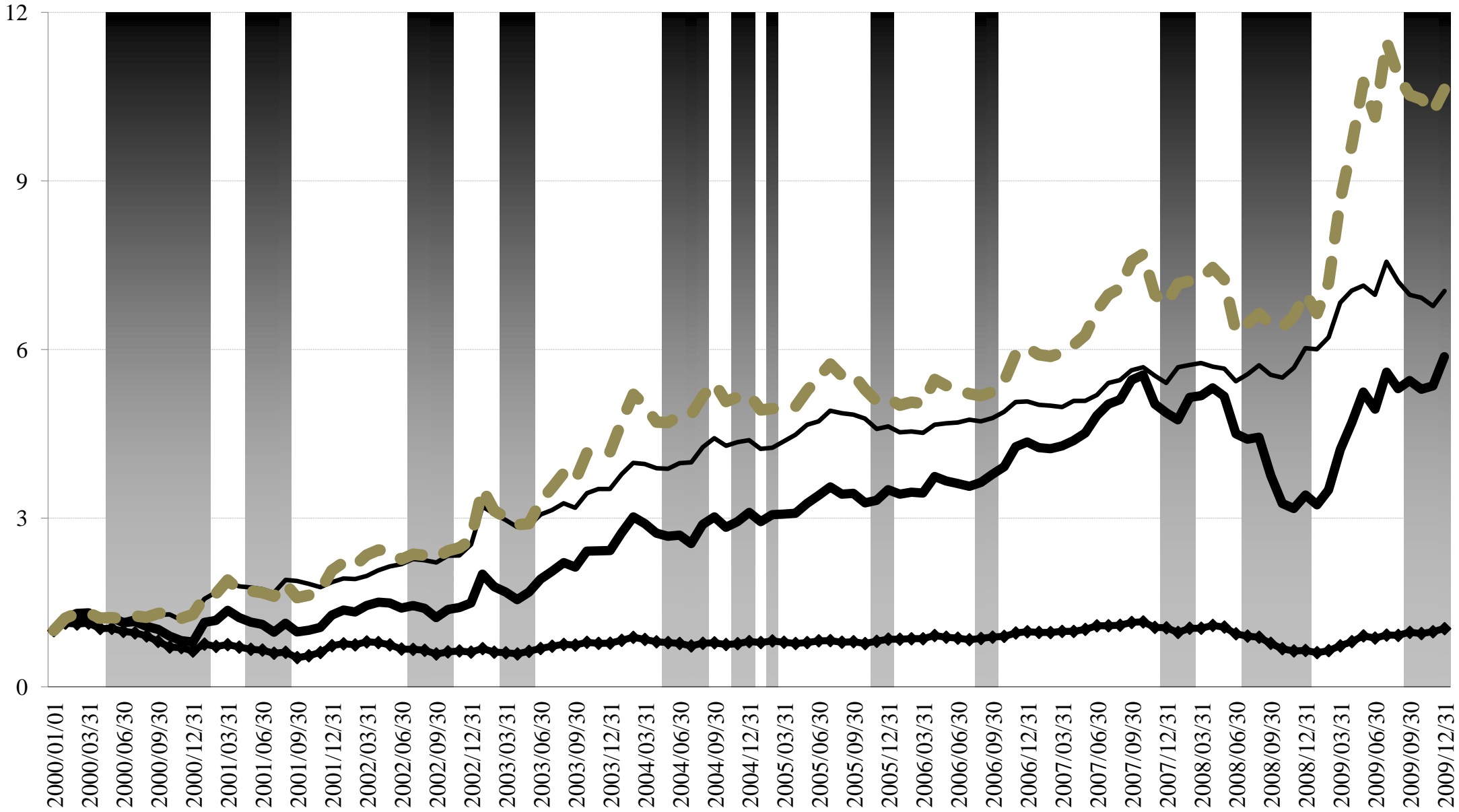


Exhibit 4: Historical Drawdowns

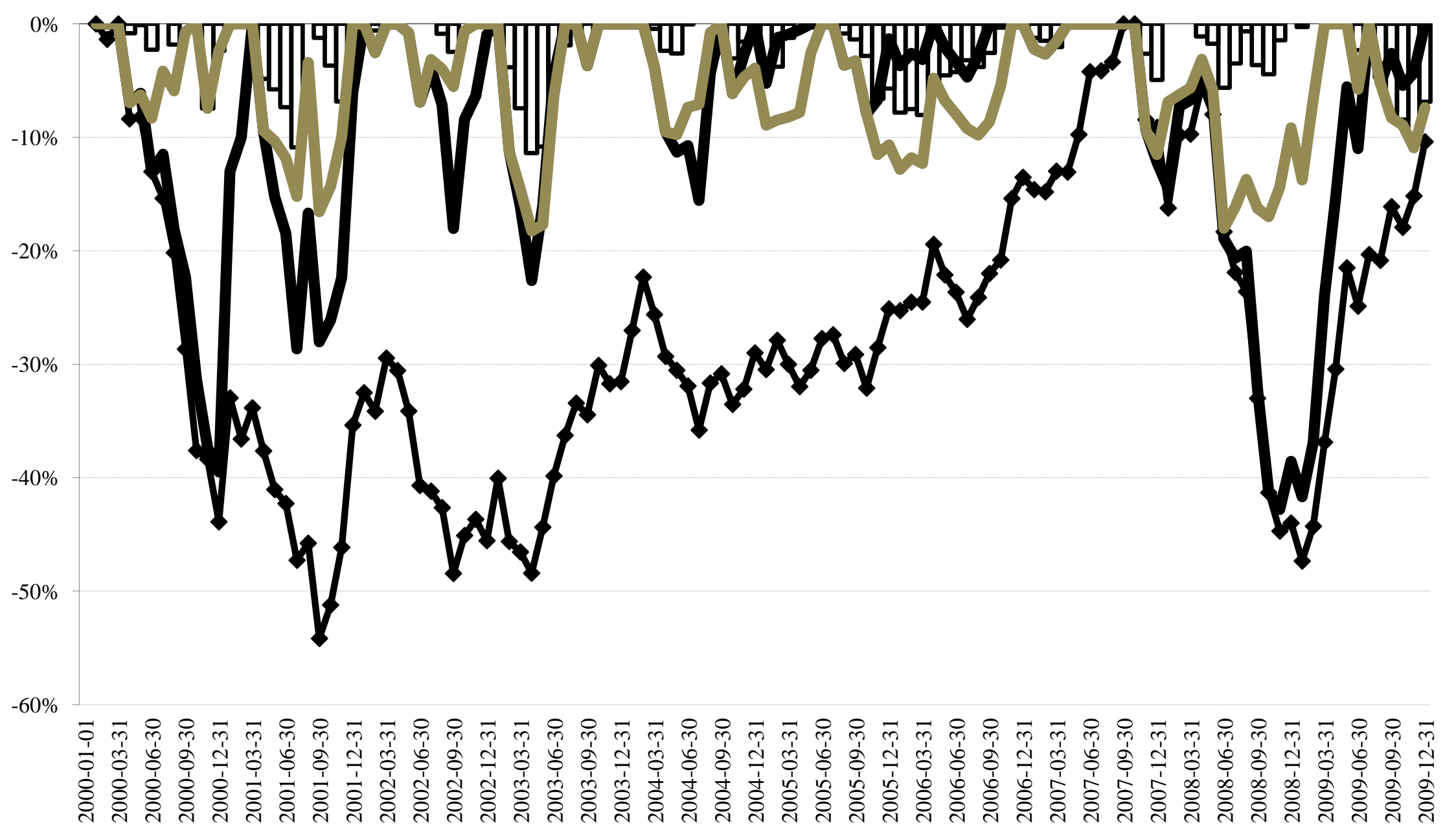




\section{CONCLUSION}

This paper proposes a 4-step procedure for developing resilient long-short hedge fund strategies for stocks traded on the Taiwan Stock Exchange. A long-only based portfolio of 50 stocks is developed. Protection mechanisms such as cash reservation and timing of the hedge are subsequently applied to the unprotected long-only portfolio to create two long-short hedge funds, namely the Hybrid Neutral fund and the Defense Fund based on the filter rule strategy. The Hybrid Neutral Fund takes on the advantage of the Market Neutral Fund and the Defense Fund in that it is constantly protected by the TAIEX short futures position, while altering the protection filter based on the fund performance. When key considerations specifically applied to the Taiwanese stock markets are taken into account, both hedge fund strategies outperform the unprotected fund, which in turn outperforms the market proxy (the TAIEX total return index). We thus recommend the application of the proposed strategies in active portfolio management for stocks traded on the Taiwan Stock Exchange. Further investigations into the proposed strategies are recommended for further research in other emerging markets.

\section{ACKNOWLEDGEMENT}

This work is supported by the National Research Foundation of South Africa. We wish to thank the research office of the University of the Western Cape for their support. Additionally, we wish to thank Professor Paul van Rensburg from the University of Cape Town and Mr. Roland Rousseau from Adex Investment Management for their special insights and valuable suggestions in this topic.

\section{AUTHOR INFORMATION}

Dr. Heng-Hsing Hsieh, CFA is the Head of Finance in the School of Business and Finance at the University of the Western Cape, South Africa. He is a CFA charterholder and a member of the South African Institute of Financial Markets (SAIFM). E-mail: ahsieh@uwc.ac.za. Corresponding Author.

Dr. Kathleen Hodnett is currently a Research Fellow (funded by the National Research Foundation (NRF) of South Africa) in the School of Business and Finance at the University of the Western Cape, South Africa. She is a member of the International Institute of Forecasters (IIF) and an associate member of the South African Institute of Financial Markets (SAIFM).

\section{REFERENCES}

1. Amenc N, Goltz F and Le Sourd V (2006), “Assessing the Quality of Stock Market Indices”, EDHEC Publication

2. Amenc N, Philippe M, Lionel M and Sfeir D (Summer 2003), "Tactical Style Allocation - A New Form of Market Neutral Strategy", EDHEC Risk and Asset Management Research Centre

3. Baghai-Wadji R and Klocker S (2007), "Performance and Style Shifts in the Hedge Fund Industry", London Business School, Working Paper, 1-48

4. Ballio M, Getmansky M and Pelizzon L (2006), "Dynamic Risk Exposure of Hedge Funds: A RegimeSwitching Approach", Working Paper, 1-55

5. Ballio M, Getmansky M and Pelizzon L (2009), "Crises and Hedge Fund Risk", Working Paper, 1-60

6. Banz R W (1981), “The Relationship between Return and Market Value of Common Stocks", Journal of Financial Economics, no. 9, 3-18

7. Basu S (1977), "The Investment Performance of Common Stocks in Relation to Their Price to Earnings Ratio: A Test of the Efficient Markets Hypothesis", Journal of Finance, vol. 32, no. 3, 663-682

8. Calson M and Steiman J (2008), "Market Conditions and Hedge Fund Survival", Finance and Economics Discussion Series, Divisions of Research and Statistics and Monetary Affairs, Federal Reserve Board, Washington, D.C.

9. Chan L K C and Lakonishok J (2004), "Value and Growth Investing: Review and Update", Financial Analysts Journal, vol. 60, no. 1,71-86

10. Chen A and Tu E H (2000), "Factor Models under Firm Characteristics in Emerging Markets: A Study of Taiwan Stock Returns", National Sun Yat-Sen University, Working Paper 
11. Cheng T, Lai H and Tsai P (2005), "On the Two-Stage Estimation of Fama-French Three Factor Models: Evidence from Taiwan", Working Paper

12. Chiao C, Hung W and Yao C (2010), "The Absence of the Book-to-Market Effect in the Taiwan Stock Market: A Decomposition Approach", The Japanese Economic Review, vol. 61, no. 2

13. Chopra N, Lakonishok J and Ritter J R (1992), "Measuring Abnormal Performance - Do Stocks Overreact?", Journal of Financial Economics, no. 31, 235-268

14. Christopherson J A and Williams C N (1997), "Equity Style: What It is and Why It Matters", The Handbook of Equity Style Management, edited by Coggin T D, Fabozzi F J and Arnott R D, New Hope, Frank J. Fabozzi Associates, Pennsylvania, 1-19

15. Daniel K, Hirshleifer D and Subrahmanyam A (December 1998), "Investor Psychology and Security Market Under- and Overreactions", Journal of Finance, vol. 53, no. 6, 1839-1885

16. De Bondt W F M and Thaler R H (July 1985), "Does the Stock Market Overreact?”, Journal of Finance, vol. 40, no. 3, 793-805

17. De Bondt W F M and Thaler R H (July 1987), "Further Evidence on Investor Overreaction and Stock Market Seasonality”, Journal of Finance, vol. 42, no. 3, 557-581

18. Exley C J, Smith A D and Wright T (2004), "Mean Reversion and Market Predictability", Stable Inn Actuary Society

19. Faber M T (2009), “A Quantitative Approach to Tactical Asset Allocation”, Journal of Wealth Management, 1-47

20. Fama E F and French K R (1992), "The Cross-Section of Expected Stock Returns", Journal of Finance, vol. 47, 427-465

21. Fama E F and French K R (1993), "Common Risk Factors in the Returns on Stocks and Bonds", Journal of Financial Economics, vol. 33 no. 1, 3-56

22. Fernholz R, Garvy R and Hannon J (1998), "Diversity-Weighted Indexing”, Journal of Portfolio Management, vol. 24, no. 2, 74-82

23. Forner C and Marhuenda J (2003), "Contrarian and Momentum Strategies in the Spanish Stock Market Seasonality”, Journal of Finance, vol. 42, no. 3, 557-581

24. Fraser E and Page M J (2000), "Value and Momentum Strategies: Evidence from the JSE", Investment Analysts Journal, no. 51, 25-35

25. Fung W and Hsieh D A (1998), "Performance Attribution and Style Analysis: From Mutual Funds to Hedge Funds", Paradigm Financial Products, Principal Publisher

26. Graham J R and Harvey C R (November/December 1997), "Grading the Performance of Market-Timing Newsletters”, Financial Analysts Journal, vol. 53, no. 6, 54-66

27. R C (1999), "Mean-Variance and Scenario-Based Approaches to Portfolio Selection", Journal of Portfolio Management, vol. 25, no. 2, 10-22

28. Haugen R A and Baker N L (1996), "Commonality in the Determinants of Expected Stock Returns", Journal of Financial Economics, no. 41, 401-439

29. Hirshleifer (2001), "Investor Psychology and Asset Pricing”, Journal of Finance, vol. 56, no 4, $1533-1597$.

30. Hodnett K (2010), "Analysis of the Cross-Section of Equity Returns on the JSE Securities Exchange based on Linear and Nonlinear Modelling Techniques”, Unpublished Doctoral Thesis, University of Cape Town.

31. Hodnett K and Hsieh H (2012), "Application of Cascade-Correlation Neural Networks in Developing Stock Selection Models for Global Equities”, International Business and Economics Research Journal, vol 11, no. 4, 375-396

32. Hsieh H (2010), “Applications of Global Equity Style Indices in Active and Passive Portfolio Management", Unpublished Doctoral Thesis, University of Cape Town.

33. Hsieh H, Hodnett K and van Rensburg P (2012a), "Application of Tactical Style Allocation for Global Equity Portfolios", International Business and Economics Research, Forthcoming.

34. Hsieh H, Hodnett K and van Rensburg P (2012b), "Resilient Market Timing Strategies for Global Equities", Journal of Applied Business Research, Forthcoming.

35. Hsu J C (2006), “Cap-Weighted Portfolios are Sub-optimal Portfolios”, Journal of Investment Management, vol. 4, no. 3, 1-10

36. Hsu J C and Campollo C (January/February 2006), "New Frontiers in Index Investing: An Examination of Fundamental Indexation”, Journal of Indexes, 32-38 
37. Jegadeesh N and Titman S (March 1993), "Returns to Buying Winners and Selling Losers: Implications for Stock Market Efficiency", Journal of Finance, vol. 48, no. 1, 65-91

38. Kao D and Shumaker R D (January/February 1999), "Equity Style Timing”, Financial Analysts Journal, vol. 55 , no $1,37-47$

39. Maestro Investment Consulting (2009), "General Prospectus of the Maestro Long Short Equity Fund”, Capstone 96 (PTY) Ltd.

40. Markowitz H M (March 1952), "Portfolio Selection", Journal of Finance, vol. 7, no. 1, 77-91

41. Mutooni R and Muller C (2007), "Equity Style Timing”, Investment Analysts Journal, no. 65, 15-24

42. Nofsinger J R (2005), “The Psychology of Investing”, $3{ }^{\text {rd }}$ Edition, Prentice Hall

43. Oldham G and Kroeger J A (2005), "Performance, Persistence and Benchmarks of Selected South African Unit Trusts for the Period 1998-2002”, South African Journal of Business Management, vol. 36, no. 4, 8190

44. Roll R (1977), “A Critique of the Asset Pricing Theory’s Tests Part I: On Past and Potential Testability of the Theory", Journal of Financial Economics", vol. 14, no. 2, 129-176

45. Samuelson P (Spring 1965), "Proof That Properly Anticipated Prices Fluctuate Randomly", Industrial Management Review, vol. 6, no. 2, 41-49

46. Sheu H, Wu S and Ku K (1998), "Cross-Sectional Relationships between Stock Returns and Market Beta, Trading Volume, and Sales-to-Price in Taiwan”, International Review of Financial Analysis, vol. 7, no. 1, 1998, 1-18

47. Shyu S, Jeng Yi, Ton W H, Lee K and Chuang H M (2006), "Taiwan Multi-Factor Model Construction: Equity Market Neutral Strategies Application”, Managerial Finance, vol. 32, no. 11, 915-947

48. Sorensen E H, Miller K L and Samak V (1998), "Allocating between Active and Passive Management", 48.Financial Analysts Journal, vol. 54, no. 5, 18-31

49. Vardharaj R and Fabozzi F J (2007), "Sector, Style, Region: Explaining Stock Allocation Performance", Financial Analysts Journal, vol. 63, no. 3, 59-70 